\title{
VARGA RÓBERT
}

\section{A kifogástalanéletvitel-ellenőrzés tapasztalatai, a bírósági gyakorlat bemutatása}

Rendőrnek, tüzoltónak pénzügyőrnek lenni nem csak munkaidőben, nyolctól négyig tartó elfoglaltság. Az ilyen hivatást választó embereknek a magánéletükben is figyelemmel kell lenniük arra, hogy viselkedésükön keresztül az egész szervezetet megítélik, így akkor is ,jól kell viselkedniük”, ha nem dolgoznak, továbbá hogy tölük mást várnak el a civilek és az a szervezet, amelyhez tartoznak, mint a nem hivatásos személytöl.

A hivatás és a magánélet elválaszthatatlan kapcsolatát a törvényalkotó is felismerte, és a jelentkezők „szürését”, annak megállapítását, hogy hivatásosként ki alkalmazható, már szabályozta és a felvételi eljárás részévé tette. Ez azonban nem jelentett egy részletes vizsgálatot, általában a nyilvántartásokban történő ellenőrzést és egy rendőri jelentést tartalmazott, amely a jelentkező lakóhelyén tapasztaltakat foglalta össze. A hivatásos jogviszony fennállása alatti magánélet vizsgálatának lehetőségét az 1996. szeptember 1-jén hatályba lépő, a fegyveres szervek hivatásos állományú tagjainak szolgálati viszonyáról szóló 1996. évi XLIII. törvény (a továbbiakban: Hszt.) már szerepeltette a méltatlanná válás jogintézménye címén, a következők szerint [56. § (6) bekezdés c) pont]:

„A hivatásos szolgálatra méltatlan az, aki szolgálaton kivüli magatartásával a fegyveres szerv müködéséhez szükséges közbizalom fenntartását súlyosan veszélyezteti."

A méltatlanná válás megállapitásának részletes szabályait elöször a belügyminiszter irányítása alá tartozó szervek, valamint az önkormányzati tüzoltóság szolgálati viszonyban álló tagjai szolgálati viszonyának egyes kérdéseiről és a személyügyi igazgatás rendjéről szóló 9/1997. (II. 12.) BM rendelet tartalmazta az etikai eljárás keretében, majd 2006-tól a belügyminiszter irányítása alatt álló fegyveres szervek hivatásos állományú tagjainak fegyelmi szabályzatáról szóló 11/2006. (III. 14.) BM rendelet azt már méltatlansági eljárásként nevesítette. Az elv azonban nem változott, a szolgálaton kívüli magatartást a foglalkoztató fegyveres szerv vizsgálta, és ez döntött a méltatlanság kérdésben is. Méltatlanság kérdésében fokozatok - mint egy fegyelmi eljárásban - nem voltak, vagy méltatlan volt az eljárás alá vont, vagy 
nem. A méltatlanság megállapítása pedig maga után vonta a szolgálati jogviszony megszüntetését.

A Hszt. 2011. január 1-jén hatályba lépő módosítása vezette be a kifogástalan életvitel ellenőrzésének szabályait, és ezzel új alapokra helyezte a szolgálaton kívüli magatartás vizsgálatát. A módosítást az egyes rendészeti tárgyú és az azokkal összefüggő törvények módosításáról szóló 2010. évi CXLVII. törvény tartalmazta. E törvény indokolása szerint „A rendörséggel szemben fennálló szakmai igények, a közbiztonság helyzetének javitására irányuló célkitüzések teljesitéséhez, továbbá Magyarországnak a rendörség feladataival összefüggö egyes jogharmonizációs kötelezettségei teljesitéséhez szükséges a hatályos szabályozási környezet megfelelö átalakitása. A törvény ennek érdekében tartalmazza a rendészeti tárgyú - elsösorban a rendörség szervezetére és a rendörség hivatásos állományának szolgálati viszonyára vonatkozó -, valamint az ezzel összefüggö más törvények módositását. A szabályozás kialakitását alapvetōen meghatározza a feladat-ellátás hatékonyságának növelésére, a belügyminiszter irányitása alatt álló szervek tevékenységében megnyilvánuló párhuzamosságok megszüntetésére, az intézkedések jogszerüségének fokozására, az államigazgatás tisztaságának növelésére vonatkozó társadalmi igény.

A kifogástalan életvitel követelményét a törvény egységesen, a Hszt. hatálya alá tartozó minden, hivatásos állományban szolgálatot teljesitôre kiterjeszti, ezért a kifogástalan életvitelre vonatkozó szabályok a Hszt. általános részében kerülnek elhelyezésre. Ugyancsak általános szabályként tartalmazza a törvény a hivatásos állomány tagja vonatkozásában annak vállalását, hogy a szolgálati viszonya fennállása alatt a tudta és beleegyezése nélkül szolgálata törvényes ellátása ellenörizhetö (megbízhatósági vizsgálat). A kifogástalan életvitel követelményeinek való megfelelés ellenőrzését, valamint a megbizhatósági vizsgálatot a belsö bünmegelozzési és bünfelderitési feladatot ellátó szerv - amely rendöri szervre vonatkozó rendelkezéseket az Rtv. módositása tartalmazza végzi. [...] A törvény kiegésziti a Hszt.-t azzal kapcsolatban, hogy ha a hivatásos állomány tagja 2011. január 1-je elött megfelelt a kifogástalan életvitel követelményének, vele szemben a Hszt. 37/A. \$-ban meghatározott kizáró ok csak újabb büncselekmény elkövetése esetén alkalmazható, továbbá a méltatlansági eljárás tekintetében is biztositja az átmeneti rendelkezést."

$\mathrm{Az}$ indokolásból is látható, hogy a törvényalkotó szakítani kívánt a régi rendszerrel, és új néven egy új jogintézményt vezetett be. Jelen tanulmánynak nem célja a méltatlansági eljárás és a kifogástalanéletvitel-ellenőrzés összehasonlítása, de kiemelhetők a következő jelentős különbségek: 
- a kifogástalanéletvitel-ellenőrzésre sor kerülhet az állományba vétel előtt és a jogviszony fennállása alatt is - a méltatlansági eljárás csak az állományban lévőre terjed ki;

- a kifogástalanéletvitel-ellenőrzést a foglalkoztató szervtől elkülönülő, önálló szerv végzi, és e szervnek szélesebb körü eljárási jogai vannak, mint a méltatlansági eljárás során - a méltatlansági eljárást a munkáltató folytatja le.

\section{Kifogástalanéletvitel-ellenőrzés a gyakorlatban}

A kifogástalan életvitel ellenőrzésének szabályait egyrészről a Hszt., másrészröl a rendőrség belső bünmegelőzési és bünfelderítési feladatokat ellátó szerve kijelöléséről, valamint feladatai ellátásának, a kifogástalanéletvitel-ellenőrzés és a megbízhatósági vizsgálat részletes szabályainak megállapításáról szóló 293/2010. (XII. 22.) kormányrendelet (a továbbiakban: kormányrendelet) tartalmazza. A kormányrendelet alapján a belső bünmegelözési és bünfelderítési feladatokat ellátó szerv a Nemzeti Védelmi Szolgálat.

Az új jogintézmény gyakorlati megvalósítása a Nemzeti Védelmi Szolgálat számára is nehézséget okozott, bár a jogszabályi alapok adottak voltak a 2011. január 1-jei induláskor. A Hszt. 37. § (1) bekezdése szerint a hivatásos szolgálati viszony önkéntes jelentkezés alapján azzal a tizennyolc évesnél idősebb, de harminchét évesnél fiatalabb, cselekvőképes, állandó belföldi lakóhelyü, a rendfokozati állománycsoporthoz meghatározott iskolai végzettségü, szakképzettségü magyar állampolgárral létesíthetö - többek között -, akinek életvitele nem kifogásolható, és hozzájárul annak a szolgálati viszony létesítése elötti, valamint a szolgálati viszony fennállása alatti ellenőrzéséhez. E szakasz (6) bekezdése szerint a fegyveres szerv az (1) és (5) bekezdésben meghatározott adatokat, illetve a feltételeknek való megfelelést a szolgálati viszony fennállása alatt ellenőrizheti.

Az induláskor a Hszt. a következő rendelkezéseket is tartalmazta:

„37/B. § (1) Hivatásos szolgálati viszony a 37. § (1) bekezdésében meghatározott feltételeken túl akkor létesithetö vagy tartható fenn, ha a hivatásos állomány tagja vagy a jelentkezö

a) életvitele kifogástalan, és

b) irásban hozzájárul

ba) a 7. számú mellékletben meghatározott személyes adatai és bünügyi személyes adatai kezeléséhez, 
bb) életvitele kifogástalanságának ellenörzése érdekében a felvételét megelözöen és a szolgálati viszony tartama alatt a (2) bekezdésben meghatározottak ellenörzéséhez.

(2) Az életvitel kifogástalan, ha a hivatásos állomány tagja vagy a jelentkezö

a) esetében nem állnak fenn - a hivatásos állomány tagja esetében a folyamatban lévö büntetöeljárás kivételével - a 37/A. § (1) bekezdésében meghatározottak, és

b) megfelel - különös tekintettel a szolgálaton kívüli magatartására, családi és lakókörnyezeti kapcsolataira, anyagi, jövedelmi viszonyaira, valamint a büncselekményt elkövetö vagy azzal gyanúsitható személyekkel fenntartott kapcsolatára - a szolgálat törvényes, befolyástól mentes ellátására.

(3) A (2) bekezdésben irt feltételek ellenörzését - ha törvény másként nem rendelkezik - a rendörségröl szóló törvényben meghatározott belsö bünmegelózési és bünfelderitési feladatokat ellátó szerv végzi. A nemzetbiztonsági szolgálatok a saját munkatársaikra vonatkozóan végzett külön törvény szerinti biztonsági ellenörzés alkalmával adatszolgáltatás végett e szervet megkeresik. A megkeresett szerv a biztonsági ellenörzéssel érintett körben adatszolgáltatásra köteles.

(4) A rendörségröl szóló törvényben meghatározott belsö bünmegelözési és bünfelderitési feladatokat ellátó szerv a (2) bekezdésben foglaltak ellenörzése során a) a hivatásos állományba jelentkezöröl, valamint a hivatásos állomány tagjáról, továbbá a vele közös háztartásban élő hozzátartozóról a bünügyi nyilvántartó szerv valamennyi bünügyi nyilvántartásából, továbbá a rendészeti szervek nyilvántartásaiból adatot igényelhet, az e szerveknél folyamatban lévö vagy befejezett fegyelmi eljárás irataiba betekinthet,

b) a hivatásos állományba jelentkezöröl, vagy a hivatásos állomány tagjáról lakóhelyén, tartózkodási helyén, munkahelyén - nyiltan vagy a rendöri jelleg leplezésével - környezettanulmányt készithet."

A kormányrendelet 7-9. §-a szabályozza a kifogástalanéletvitel-ellenőrzést, ennek folyamán meghatározza a kezdeményezök körét, és a megkeresés tartalmi elemeit, mellékleteit. Az ellenőrzés határideje harminc nap, amely egy esetben harminc nappal meghosszabbítható.

A kormányrendelet alapján a befejező határozaton kívül egy kötelező eljárási cselekményt kell végrehajtani: az ellenőrzést végzőnek összesítő jelentést kell készítenie. A további eljárási cselekmények során a Nemzeti Védelmi Szolgálat alakította ki a szabályokat annak érdekében, hogy az esetleges bírósági eljárásban is megalapozott bizonyítékok álljanak rendelkezésre (pél- 
dául a meghallgatásokról jegyzőkönyv készítése, amit a meghallgatott aláírhat). A kifogástalanéletvitel-ellenőrzés idején nyílt eljárási cselekmények történnek (adatigénylések a nyilvántartásokból, környezettanulmányok készítése). Létrejön az ellenőrzöttel a személyes kapcsolatfelvétel, valamint az általa életvitelszerüen használt lakóhely megtekintése is.

A kezdetekkor a védelmi szolgálat dolgozóinak munkaidejét jelentős részben lekötötte a kifogástalanéletvitel-ellenőrzés elvégzése. 2011-ben 6155 kifogástalanéletvitel-ellenőrzés fejeződött be. Az elrendelt és már határozattal lezárt ellenőrzések alapján 123 esetben állapították meg a kifogásolható életvitelt, továbbá 146 esetben egyéb módon (például a vizsgálat alatt álló elállt a hivatásos szolgálatba történő jelentkezéstöl) zárult a kifogástalan életvitel ellenőrzése.

Az ellenőrzésekkor a védelmi szolgálat munkatársai is számos kérdéssel szembesültek, ezek közül a következők érdemelnek kiemelést:

- 2011 második fél évében szükségessé vált az eljárási metodika részbeni újragondolása (például a környezettanulmányok végzése, és az eközben felvett adatok rögzítésének alaki szempontjai) a gyakorlati tapasztalatok alapján.

- Az életvitel-ellenörzés nemcsak a Nemzeti Védelmi Szolgálatnak, hanem a hivatásos személyt foglalkoztató szervnek is új volt, ezért egységesíteni kellett az ellenőrzés adminisztrációjának alaki követelményeit.

- Több esetben kellett a védett szervekkel tisztázni, hogy a kifogástalanéletvitel-ellenőrzés nem helyettesítheti a korábbi méltatlansági eljárást, mivel a hatályos szabályozás szerint a büntetőeljárás alá vont hivatásos esetén (az eljárás jogerős befejezéséig) nem lehet kimondani, hogy - csak a folyamatban lévő büntetőeljárásra tekintettel - az életvitele kifogásolható. A munkáltató számára mindenkor adott volt az a lehetőség, hogy ha hivatásos állomány tagja a szolgálati viszonyból eredő kötelezettségeivel össze nem függő büncselekmény miatt a büntetőeljárásban a terhére rótt bủncselekmény elkövetését beismerte, vagy tetten érték, és megfelelő bizonyítékok állnak rendelkezésre, a hivatásos szolgálatra alkalmatlanná válást a büntetőeljárás jogerős befejezése előtt is meg lehet állapítani, nem volt szükséges kezdeményezni a kifogástalanéletvitel-ellenőrzést.

- Nehezen kezelhető probléma volt, hogy a kifogástalanéletvitel-ellenőrzések a kezdeményező szervektől nem egyenletesen, hanem „kampányszerüen”, egyszerre nagy számban érkeztek, jellemzően az új hallgatók beiskolázásakor.

Az eltelt években számos technikai változás történt, amelyek megkönnyítik az életvitel-ellenörzések végrehajtását. Például létrejött a Robotzsaru Neo fe- 
lületen keresztül történő (a BM Alkotmányvédelmi Hivatal, illetve a Közigazgatási és Elektronikus Közszolgáltatások Központi Hivatalának nyilvántartásaira is kiterjedő) kötegelt lekérdezési modul, amelynek használata nagyban gyorsítja a tömeges kifogástalanéletvitel-ellenőrzések elvégzését, a szükséges nyilvántartásokban történő ellenőrzést.

A gyakorlati tapasztalatok alapján jogszabály-módosítások is történtek. 2012. január 1-jével a jogalkotó szigorú szankciót illesztett a Hszt. rendelkezései közé: ha a hivatásos állomány tagja 2012. február 28-ig nem járult hozzá írásban a kifogástalan életvitel ellenőrzéséhez, szolgálati viszonyát felmentéssel, hivatásos szolgálatra alkalmatlanság miatt meg kellett szüntetni. Ez is jelzi, hogy a jogalkotó kiemelt hangsúlyt helyezett a kifogástalanéletvitel-ellenörzés fontosságára.

2012. július 1-jén módosult a 64/2011. (XII. 30.) BM rendelet, ennek megfelelően a kifogástalanéletvitel-ellenőrzés csak abban az esetben kezdeményezhetö, ha a jelölt az egészségi, pszichológiai és fizikai alkalmassági feltételeknek megfelel.

2012-től módosult a kormányrendelet is, kiegészült az életvitel-ellenőrzés felfüggesztésének a lehetöségével, és a megszüntetés eseteit is pontosan rögzítették. A hatálybalépéskor a kormányrendelet melléklete tartalmazta a hivatásos szolgálati viszonyt létesítő személy kifogástalan életvitele ellenőrzéséhez szükséges adatlapot, adatvédelmi okokból azonban az adatlap 2012. január 1-jétől a Hszt. mellékletében szerepel.

A Hszt. kifogástalanéletvitel-ellenőrzésre vonatkozó rendelkezéseinek legjelentősebb módosítására 2013. január 1-jén került sor. Ez után a Nemzeti Védelmi Szolgálat csak a hivatásos állományba vagy rendvédelmi oktatási intézménybe jelentkező esetében állapíthatta meg az életvitel kifogásolhatóságát.

A hivatásos állomány tagja esetében az állományilletékes parancsnok, az ösztöndíjas hallgató, valamint a tanuló esetében az ösztöndíjas hallgatói, illetve tanulói szerződést kötő fegyveres szerv országos parancsnoka állapítja meg a kifogásolható életvitelt. Ebben az esetben a Nemzeti Védelmi Szolgálat elvégzi az életvitel-ellenőrzést, ennek eredményéröl tájékoztatja a kezdeményezőt. Ha a vizsgálat azt állapítja meg, hogy a hivatásos állomány tagjának életvitele szubjektív alapon kifogásolható, az állományilletékes parancsnok a döntésének meghozatala elött köteles meghallgatni a hivatásos állomány tagját az életvitel kifogásolhatóságát megalapozó körülményekről. Az állományilletékes parancsnok a döntését a Nemzeti Védelmi Szolgálat által elvégzett vizsgálat megállapításai, a meghallgatás figyelembevételével és a fegyveres szerv szolgálati érdekeit is szem elött tartva hozza meg. 
Az eltelt évek alatt pozitívumként lehet értékelni, hogy a kérelmek egyre nagyobb része irányul már állományban lévő hivatásos személyek vizsgálatára, mivel a szolgálatban vagy azon kívül tanúsított magatartásukat parancsnokaik (kollégáik) a hivatásos szolgálattal nem összeegyeztethetőnek ítélik meg.

Az elrendelt és már határozattal lezárt ellenőrzések alapján néhány esetben állapították meg az életvitel kifogásolhatóságát. Az okok döntö többségében a Hszt. 37/A § (1) bekezdésében felsorolt objektív tények voltak (például jogerős bírói ítélet hátrányos jogkövetkezményeinek hatálya alatt álltak az érintettek). A Hszt. 37/B § (2) bekezdés b) pontjában meghatározott úgynevezett szubjektív okokra (például családi, lakókörnyezeti kapcsolatok, bünelkövetőkkel tartott kapcsolatok) kevés ellenőrzésen derült fény.

A Nemzeti Védelmi Szolgálat megalakulása óta a befejezett kifogástalanéletvitel-ellenőrzések száma folyamatos csökkenést mutat: 2011: 6155; 2012: 4406; 2013: 3851; 2014: 3125. A csökkenés egyebek között a következő okokra is visszavezethető:

- a nemzetbiztonsági ellenőrzés és az életvitel-ellenőrzés egymáshoz viszonyított kapcsolatának rendezése: a párhuzamos munka elkerülése érdekében nem végzünk életvitel-ellenőrzést a nemzetbiztonsági ellenőrzés hatálya alá tartozó beosztást betöltők esetében;

- az egyes rendvédelmi szervek állományának stabilizálódása;

- a szervezetrendszer struktúrájának kialakulása, és a fluktuáció csökkenése.

Összességében megállapítható, hogy a Nemzeti Védelmi Szolgálat védelmi tisztjei a kifogástalanéletvitel-ellenőrzéseket már kellő rutinnal, széles körü szakmai tapasztalattal végzik.

\section{Kifogástalanéletvitel-ellenőrzés a bírósági ítéletek tükrében}

Mint minden új jogintézmény, a kifogástalanéletvitel-ellenőrzés esetében is várakozás előzte meg a bírósági határozatokat abból az okból, hogy a bírósági jogértelmezés mennyivel tér el, vagy támasztja alá a gyakorlati végrehajtást. Az első peres eljárások 2012-ben kezdődtek, amikor is két hivatásos állományban lévő a kifogásolható életvitelt megállapító határozatot követő munkáltatói intézkedés ellen bírósághoz fordult.

A kifogástalanéletvitel-ellenörzések után 2013. január 1-jéig a foglalkoztató szervnek nem volt mérlegelési lehetősége, ha a Nemzeti Védelmi Szol- 
gálat azt állapította meg, hogy az ellenőrzés alá vont életvitele kifogásolható, akkor felmentéssel, alkalmatlanság miatt meg kellett szüntetni az érintett hivatásos szolgálati jogviszonyát. Ebben az esetben sem felmentési idő, sem végkielégítés nem járt a hivatásosnak.

A hivatásos jogviszonyban állók között is természetes és elfogadott a munkáltatói döntések bíróság elötti megtámadásának lehetősége. Azonban ez a kifogásolható életvitelen alapuló felmentések között nem tekinthető kimagaslónak, mert 2014. december 31-ig országos szinten csak 23 esetben fordultak bírósághoz. 2015-ben két új keresetet nyújtottak be e tárgyban.

Figyelemmel arra, hogy a hivatásos állományúak közül a kifogásolható életvitel megállapítására 2011 és 2014 között 76 személy esetében került sor, ez a szám nem tekinthető jelentősnek. E cikk írásakor a huszonöt esetből tíz jogerősen pernyertességgel, kettő elsőfokú pernyertességgel, nyolc jogerősen pervesztességgel, egy elsőfokú pervesztességgel végződött, négy eljárás még folyamatban volt.

A bíróságok pervitele eltérő, azonban döntő többségben elsődlegesen bekérték a munkáltatói döntést és az azt megalapozó kifogástalanéletvitel-ellenőrzés anyagát, majd meghallgatták a Nemzeti Védelmi Szolgálat eljáró védelmi tisztjét. A kért iratokat a bíróságok rendelkezésére bocsátottuk.

Elsődlegesen tisztázásra szorult az a kérdés is, hogy a Nemzeti Védelmi Szolgálat határozata a bíróság előtt vizsgálható-e, és ha igen, milyen módon. Ebben a kérdésben a Kúria is állást foglalt a Kfv. III.37.726/2012.5 számú, 2013. június 25-én hozott eseti döntésében, amelyben kifejtette, hogy „az NVSZ által hozott határozat ellen sem közigazgatási eljárásban, sem birói úton jogorvoslat nem terjeszthetö elö”, azonban ,, az NVSZ határozata valóban nem, azonban annak eredményeképpen tett érdemi határozatbéli megállapitások vitathatók. A felperes nem zárható el attól, hogy a határozat jogsértö volta kapcsán bizonyitást ajánljon fel, amelynek felvételét a biróság nem mellözheti."

Az elsőfokú bíróságok tehát ezt a gyakorlatot követték, és a munkáltatói döntés vizsgálata keretében áttekintették a Nemzeti Védelmi Szolgálat eljárását, annak megalapozottságát, mind eljárásjogi alapon, mind érdemben. Elsődleges célunk, hogy a Nemzeti Védelmi Szolgálat az alperes, munkáltató oldalán beavatkozóként részt vegyen a peres eljárásban. Ahol ezt a bíróság engedélyezi, elmondható, hogy nagymértékben segíteni tudjuk az alperes munkáját mind az írásos anyagokkal, mind a tanúkkal.

A kifogástalanéletvitel-ellenőrzéssel érintettek csak abban az esetben vitatták a szolgálati viszony megszüntetésének a jogszerüségét, ha a kifogásolható életvitel megállapításra a Hszt. 37/B § (2) bekezdés c) pontja alapján ke- 
rült sor, mert a jelentkező vagy a hivatásos állomány tagja nem felel meg különös tekintettel a szolgálaton kívüli magatartására, családi és lakókörnyezeti kapcsolataira, anyagi, jövedelmi viszonyaira, valamint a büncselekményt elkövető vagy azzal gyanúsítható személyekkel fenntartott kapcsolatára - a szolgálat törvényes, befolyástól mentes ellátása követelményének.

Az eddigi esetek alapján, e körben három nagy csoportot különböztethetünk meg:

- büncselekményt elkövető személlyel történő kapcsolattartás;

- anyagi, jövedelmi viszonyai, kiadásai nem állnak arányban a bevételeivel;

- egyéb szolgálaton kívüli magatartás (ittas vezetés).

A büncselekményt elkövető személyekkel történő kapcsolattartás jól bizonyítható, mert a nyilvántartások adatai (priusz) a Nemzeti Védelmi Szolgálat rendelkezésére állnak. A büncselekmények felderítésével, a nyomozással foglalkozó hivatásos személyeknek a hivatali munkájuk során, azzal összefüggésben kapcsolatot kell tartaniuk büncselekményt elkövető személyekkel, de ez elmondható a közterületi szolgálatot ellátókról is. Ebben az esetben abban kell állást foglalni, hogy ez a kapcsolattartás a megengedhetö, a jogszerü kereteken belül marad-e (például a rendőr jelentést ír a találkozókról), vagy már öncélú lesz. Általában a meg nem engedhető kapcsolattartás már olyan mértékü, hogy az az érintett kollégái elött is ismertté válik, és erről a munkatársak is elítélően nyilatkoznak. Így a munkaügyi perekben, a bizonyítási eljárásban sem vezetett eredményre az ellenőrzés alá vontak ellenbizonyítása, amely szerint hivatalból, a munkavégzése miatt tartottak kapcsolatot büncselekményt elkövető személyekkel, és a bíróság helybenhagyta a munkáltatói döntést.

Az anyagi, jövedelmi viszonyok vizsgálata azonban már nehezebben bizonyítható. A kifogástalanéletvitel-ellenőrzés nem nyomozás, és a célja is más, így a Nemzeti Védelmi Szolgálatnak is csak csekély lehetősége van a vagyoni helyzet vizsgálatára. A bírósági ítéletekből megállapítható, hogy az anyagi, jövedelmi viszonyok aránytalanságán alapuló kifogásolható életvitel megállapítása részletes vizsgálatot igényel. Célszerü a környezettanulmány során fényképfelvételeket készíteni a jelentősebb vagyontárgyakról (például családi ház, berendezések, járművek). Az általános megfogalmazást (például kiemelkedő életkörülmények, nívós burkolat, átlagon felüli életszínvonal) önmagában nem fogadja el a bíróság, meg kell magyarázni, hogy ezen mit ért a határozatot hozó. Már az életvitel-ellenőrzés idején be kell szerezni az ellenőrzés alá vont bevételeit-kiadásait tartalmazó kimutatást, ha szülői segítségre hivatkoznak (például építkezésnél munka, élelmiszer-támogatás, anya- 
gi juttatások), annak mértékét a lehető legpontosabban meg kell állapítani, és csak ezen adatok összevetése alapján lehet kimondani, hogy az ellenőrzés alá vont kiadásai nem állnak arányban a bevételeivel.

A szolgálaton kívüli egyéb magatartások esetében az adott élethelyzetet vizsgálja a bíróság azzal összefüggésben, hogy az a szolgálat törvényes, befolyástól mentes ellátását mennyiben teszi lehetetlenné. A hivatásos állomány a szolgálaton kívüli magatartása tekintetében is találékony. Volt olyan, aki szabadidejében „kisboltot” üzemeltetett, ahol hitelbe is kiszolgálta a rászorulókat. Azonban, ha nem fizettek, néha-néha szolgálatban is meglátogatta öket, továbbá jelentős kamattal kérte megfizetni a hitelbe adott kenyér, tej árát.

Az „ötletes” gondolkodást jellemzi, hogy egy hivatásos állományú személy úgy próbált meg kibújni a parkolási díj megfizetésének kötelezettsége alól, hogy a gépjármúve rendszámtábláját eltávolította a megállás után. Ezzel nemcsak az állását veszítette el, de büncselekményt is elkövetett.

A bírósági eljárások közül kiemelést érdemel az az ügy, amikor egy hivatásosnál szolgálaton kívüli ittas vezetés miatt kifogásolható életvitelt állapított meg a Nemzeti Védelmi Szolgálat. Az elbocsátott megtámadta a munkáltatói határozatot, és kérte annak hatályon kívül helyezését. A munkaügyi perben a bíróság jogerősen helyt adott a keresetnek. Az indokolás szerint azért sem alapos a kifogásolható életvitel megállapítása, mert az életvitel szó egy folyamatot jelöl, és nem egyszeri cselekményt. A felülvizsgálati kérelem után a Kúria hatályában fenntartotta az ítéletet, Mvf. II. 10.290/2014. számú itéletében azonban nem zárta ki, hogy az eset összes körülményét figyelembe véve akár egy egyszeri magatartás is alapjául szolgáljon a kifogásolható életvitel megállapításának.

Az ismertetett két eseti döntésen felül a Kúria még egyszer döntött kifogásolható életvitel megállapítása kérdésében, amikor is a bizonyítékok mérlegelése után helybenhagyta a munkáltatói döntést. A Kfv. II.37.704/2014. számú ítélet szerint „,Tekintettel arra, hogy a vizsgálat felperes esetében jogszabály elöirásaival ellentétes életvitelt állapitott meg és a vizsgálat megállapitásait felperes nem tudta megcáfolni az alperes határozatának jogsértö volta nem volt megállapitható".

A bíróságok előtti elsőfokú eljárások jellemzően megpróbálják a legteljesebb körü bizonyítást lefolytatni, hogy annak hiánya ne szolgáltasson okot másodfokon a hatályon kívül helyezésre. Általánosságban elmondható, hogy a bíróságok az olyan munkaügyi tárgyú határozatot fogadják el, amely részletes és megalapozott indokokkal alátámasztott, tehát a kifogástalanéletvitelellenőrzés idején is törekedni kell arra, hogy a határozat „több lábon álljon”. 
Az előzőek alapján megállapítható, hogy a kifogástalanéletvitel-ellenőrzés utáni munkaügyi perekben a pervitel tekintetében egységes a bíróságok gyakorlata: széles körü bizonyítást folytatnak le, vizsgálják a Nemzeti Védelmi Szolgálat határozatának megalapozottságát, és a munkáltató parancsának jogszerüségét is (például indokolási kötelezettségének eleget tesz-e a munkáltató). Továbbá az ítélkezési gyakorlat annyiban is egységes, hogy bármelyik döntés (akár a Nemzeti Védelmi Szolgálaté, akár a munkáltatóé) jogszabályba ütköző hiányossága miatt a keresetnek helyt adó határozat születik.

Ezen túl azonban az érdemi elbírálás, a bizonyítékok mérlegelése és ezek alapján a határozatoktól eltérő álláspont megállapításában már különböző a bíróságok gyakorlata.

\section{Zárszó}

Az eltelt négy évben a kifogástalanéletvitel-ellenőrzés kiállta a gyakorlat próbáját. Az az elképzelés, hogy a szolgálaton kívüli magatartást egy a foglalkoztatótól elkülönülő szerv végezze el, és ehhez széles körü eljárási garanciákat is rendelnek, beváltotta a hozzá füzött reményeket. A feladat elkülönült szerv általi végzésével nem csökkent az állományilletékes parancsnok döntési hatásköre, mert a Nemzeti Védelmi Szolgálat javaslatának birtokában szabadon dönthet arról, hogy megállapítja-e a kifogásolható életvitelt, vagy sem.

Az ellenőrzés fontos a hivatásos jogviszony fennállása alatt, de talán hangsúlyosabb az állományba vétel előtt. Ha már a jelentkezés folyamán kiszürik azt, aki nem felel meg az elvárt magasabb mércének, akkor az automatikusan az állomány öntisztulásához is vezet.

A Nemzeti Védelmi Szolgálat kialakította a kifogástalanéletvitel-ellenőrzés gyakorlati végrehajtását, továbbá annak jogszabályi alapjai szilárdak. Ezt bizonyítja az is, hogy 2015. július 1-jén hatályba lépett a rendvédelmi feladatokat ellátó szervek hivatásos állományának szolgálati jogviszonyáról szóló 2015. évi XLII. törvény, ennek 42. és 43. §-a a régi törvénnyel azonos tartalommal szabályozza e jogintézményt.

A kifogástalanéletvitel-ellenőrzést a bíróságok is megismerték, bár az e tárgyú munkaügyi perek száma nem jelentős. Új élethelyzetek mindig lesznek, a Nemzeti Védelmi Szolgálat munkatársai azonban felkészültek, és a jól kialakított gyakorlat alapján megalapozott határozatot tudnak hozni. Erre a javaslatra a munkáltató biztosan támaszkodhat. 